\title{
Changes in phosphorus content of two aquatic macrophytes according to water velocity, trophic status and time period in hardwater streams
}

\author{
Virginie Baldy $\cdot$ Michèle Trémolières • \\ Muriel Andrieu · Jacques Belliard
}

Received: 6 January 2006/Revised: 18 July 2006/ Accepted: 27 July 2006/ Published online: 25 September 2006

(C) Springer Science+Business Media B.V. 2006

\begin{abstract}
We examined the influence of water velocity, trophic status, and time period on the phosphorus content of two aquatic macrophytes. We sampled Berula erecta (Huds.) and Callitriche obtusangula (Le Gall.) from 17 oligosaprobic hardwater streams in the Alsatian Rhine floodplain of northeastern France. Sampling was conducted on a monthly basis during a 9-month period from August 1996 to April 1997. For B. erecta, phosphorus content of shoots and roots were correlated to water phosphorus content but not to sediment phosphorus content. The range of phosphorus shoot content of $C$. obtusangula was similar to that of $B$. erecta. Phosphorus shoot content of $C$. obtusangula was not correlated with water and sediment phosphorus content. In one
\end{abstract}

Handling editor: S. Magela Thomaz

V. Baldy $(\bowtie) \cdot M$. Trémolières · M. Andrieu ·

J. Belliard

Centre d'Ecologie Végétale et d'Hydrologie (CEVH),

Institut de Botanique, 28 rue Goethe, 67083

Strasbourg Cedex, France

e-mail: virginie.baldy@up.univ-mrs.fr

Present Address:

V. Baldy

Institut Méditerranéen d'Ecologie et de

Paléoécologie, Faculté des Sciences et Techniques de

St-Jérôme, UMR 6116 - Université de Provence -

LBEM, Case 421, Avenue Escadrille Normandie

Niemen, 13397 Marseille Cedex 20, France stream where both species were present on the same sampling dates, shoot phosphorus content decreased when water velocity was high, particularly for C. obtusangula. Additionally, a significant effect of time period was observed for both species when the water velocities were low. The effect of water velocity was only significant from spring (April) to autumn (October) when plant phosphorus content was highest.

Keywords Aquatic macrophytes - Water trophic status $\cdot$ Phosphorus $\cdot$ Water velocity

\section{Introduction}

Phosphorus is a key element involved in the eutrophication of waterbodies (Vollenweider, 1971). Eutrophication is a process that typically results in reduced water clarity and increased growth of algae or vascular macrophytes, but may be managed by controlling nutrient sources. As a result of their phosphorus requirements for growth (Fogg, 1973), macrophytes can play an important role in the cycling of phosphorus in aquatic systems; in particular, exchanges between sediments, the water column and plant biomass.

Considerable attention has been devoted to investigating phosphorus dynamics in lacustrine ecosystems (Löfgren \& Boström, 1989; Van Huet, 1990) and microcosm experiments (Pelton et al., 
1998 stream microcosm) that do not accurately reflect natural conditions. Previous studies reported that phosphorus is mainly assimilated by macrophytes from sediments via their roots and not from the water column via shoots (Bole \& Allan, 1978; Barko \& Smart, 1980; Carignan \& Kalff, 1980; Huebert \& Gorham, 1983; Gabrielson et al., 1984). Phosphorus uptake via shoots and roots occurs by facilitated diffusion across the plasmic membrane using transporter proteins such as $\mathrm{H}_{2} \mathrm{PO}_{4}^{-} / \mathrm{H}^{+}$symporters (Schachtman et al., 1998; Smith et al., 2003). Limited information is available on phosphorus uptake by macrophytes in streams, and the results are conflicting. Hill (1979) \& Peverly $(1979,1985)$ found no correlation between phosphorus content of water, phosphorus content of sediment and plant biomass. However, when sediment phosphorus content is low uptake of water phosphorus by macrophytes can be observed (Chambers et al., 1989; Pelton et al., 1998). Similarly, Robach et al. (1995, 1996) observed a strong correlation between plant phosphorus content and the annual mean phosphate concentration of water, but not between total plant phosphorus and total sediment phosphorus.

On a whole, these results suggest the relative contribution of water and sediment to the nutrition of macrophytes in streams is dependant on various abiotic and biotic factors. Firstly, relative trophic status of water and sediment (Best \& Mantai, 1979; Rattray et al., 1991) and particularly the amount of soluble reactive phosphorus (Denny, 1972; Pelton et al., 1998 in stream microcosms) are important abiotic factors in macrophyte nutrition. Secondly, plant morphology, and particularly the root to shoot ratio, leads to preferential nutrient sources. For example, sediment phosphorus can be the main nutrient source for strong root system plants (Denny, 1972). Finally, ecological factors such as substratum (Clarke \& Wharton, 2001), time period (Moutin et al., 1993; Maine et al., 1999; House \& Denison, 2002) and water velocity (Royle \& King, 1991; Carr \& Chambers, 1998) can modify phosphorus availability and thus plant nutrition.

The rare studies focusing on the role of water velocity on phosphorus dynamics have been evaluated in macrophyte communities (Haslam,
1982; Dawson, 1988), algal periphyton development (Ghosh \& Gaur, 1994), or sediment chemistry (Prairie \& Kalff, 1988; Chambers et al., 1992; Chambers \& Prepas, 1994). These studies reported a relatively long-term effect of hydrological regimes on phosphorus dynamics, with a positive or negative correlation between dissolved phosphorus and water discharge, varying in magnitude and in direction among streams. However, there is no literature available on the role of water velocity on phosphorus storage by macrophytes in lotic ecosystems, according to the relative contribution of phosphorus content in water and sediment.

Our objective was to examine the influence of water velocity, total phosphorus in the water and sediment (trophic status), and time period on the phosphorus content of two aquatic macrophytes within hardwater streams. We report investigations on phosphorus storage within two common aquatic macrophytes (Berula erecta (Huds.) Coville, and Callitriche obtusangula Le Gall.) in hardwater streams with different water velocities. Both species have a wide trophic amplitude, but C. obtusangula is thought to prefer pool habitat, while $B$. erecta prefers riffle habitats. In addition, $B$. erecta exhibits a strong root system and a strictly submerged growth form and C. obtusangula has few developed roots, and floating (emergent) and submerged shoots. Morphological differences between the two species may influence their modes of nutrition.

\section{Materials and methods}

\section{Study sites}

We chose 19 sampling sites for B. erecta in 10 streams and 25 sampling sites for $C$. obtusangula in 15 streams. All sites were located within oligosaprobic [organic-matter poor streams (Hawkes, 1962; Haslam, 1990)] hardwater streams within a $60 \mathrm{~km}$ reach of the Alsatian Rhine floodplain of north-eastern France $\left(48^{\circ} 05^{\prime}-\right.$ $48^{\circ} 35^{\prime} \mathrm{N}, 7^{\circ} 30^{\prime}-7^{\circ} 46^{\prime} \mathrm{E}$ ). The primary land use in the study area is agriculture. Physico-chemical characteristics of the streams are summarized in Table 1. B. erecta and C. obtusangula occurred 
Table 1 Chemical characteristics of the streams (from August 1996 to April 1997)

\begin{tabular}{llcr}
\hline Parameter & $N$ & Mean & \multicolumn{1}{c}{ SD } \\
\hline pH & 90 & 7.5 & 0.6 \\
Conductivity $\left(\mu \mathrm{S} / \mathrm{cm}, 20^{\circ} \mathrm{C}\right)$ & 124 & 722 & 116.4 \\
Temperature $\left({ }^{\circ} \mathrm{C}\right)$ & 241 & 10.8 & 3.4 \\
Oxygen $(\%$ of saturation) & 167 & 70.9 & 23.6 \\
Calcium $\left(\mathrm{mg} \mathrm{l}^{-1}\right)$ & 23 & 64.2 & 16.3 \\
\hline
\end{tabular}

$N=$ n umber of observations, SD = Standard Deviation. Calcium content values came from Sanchez-Pérez \& Trémolières (2003)

together at 14 stations in eight streams (all in all 17 streams and 30 stations). Phosphorus concentrations in the streams ranged from $[\mathrm{P}-$ $\left.\mathrm{PO}_{4}^{3-}\right]<5 \mu \mathrm{g} \mathrm{l}^{-1}$ (oligotrophic) to $\left[\mathrm{P}-\mathrm{PO}_{4}^{3-}\right]$ about $50 \mathrm{~g} \mathrm{~g}^{-1}$ (meso-eutrophic). Water velocity among stations ranged from $0.03 \mathrm{~m} \mathrm{~s}^{-1}$ (stagnant waters) to $0.64 \mathrm{~m} \mathrm{~s}^{-1}$. Wet width $(5-7 \mathrm{~m})$ and water depth $(0.6-1.5 \mathrm{~m})$ were relatively homogenous among sampling sites, but $B$. erecta sites were composed of predominately gravel substrate and $C$. obtusangula sites were predominately mud substrate.

Field and laboratory methods

Sampling took place between August 1996 and April 1997. At each station, stream water (collected in tubes rinsed with stream water; one sample per station), roots and shoots of $B$. erecta and shoots of $C$. obtusangula were collected monthly. In each case, plant samples were composite of several individuals. In addition, every 2 months, core sediments were collected $(5 \mathrm{~cm}$ upper layer sediment). Water velocity was determined with a helix turnstile just upstream of the collected plants and $10 \mathrm{~cm}$ below the surface. Water temperature, oxygen content and conductivity were measured in situ with $\mathrm{WTW}^{\circledR}$ portable instruments.

Water samples were stored in the laboratory for 2 and 4 days at $3-4^{\circ} \mathrm{C}$ until analysis. Plants were rinsed with tap water to remove attached organisms and sediment. Roots, shoots and sediments were air dried for 2 weeks. Preliminary tests found for these macrophytes species among others that shoots and roots dry weight and phosphorus content results were similar between air drying for
2 weeks and $60^{\circ} \mathrm{C}$ oven drying for 3 days ( $T$-tests, $P<0.05$; Eglin \& Robach, 1992). Samples were then crushed in a MM 2000 Retsch ball crusher and passed through a 2-mm sieve. Subsamples ( $1 \mathrm{~g}$ sediment, $0.5 \mathrm{~g}$ shoot, $0.1 \mathrm{~g}$ root) were digested according to the nitro-perchloric method (AFNOR, 1986). Then, all phosphorus forms were converted into orthophosphates. Orthophosphates of water (without digestion), digested plant and sediment were analyzed by colorimetry after addition of ammonium molybdate and ascorbic acid with a microflow auto-analyser (Alliance Instruments Integral ETC), according to spectrometric method (AFNOR, 1986).

Data analysis

To test the impact of water velocity, $T$-tests were performed on phosphorus content on plant parts sampled at stations characterized by low ("L": $V \leq 0.4 \mathrm{~m} / \mathrm{s}$ ) and high ("H": $V>0.4 \mathrm{~m} / \mathrm{s}$ ) water velocity. We considered all sampling dates and species separately. Pearson correlations were performed to examine the relationships of phosphorus content among stream water, sediment, roots and shoots.

To assess the role of water velocity, sampling date (time period), species, and their interactions on plant phosphorus content, stations where both species ( $B$. erecta and $C$. obtusangula) were present at different water velocities (low and high) and dates (seven dates from August to October 1996 and January to April 1997) were studied for one stream (Ischert). With results on this stream, an unreplicated three factor ANOVA was conducted with water velocity, sampling date and species as factors, after data normality and homocedaticity were verified. Unreplicated ANOVA is recommended (Sokal \& Rohlf, 1995; Quinn \& Keough, 2002) in our case because we do not have blocks' replications, but we have a lot of repetitions within treatments (low and high velocities), allowing us to calculate residual error. We chose to study many points along streams instead of blocks' replications within one point in order to include stream heterogeneity without making heavy field sampling. Precedent experiments without replication have shown a rather good power of ANOVA tests $(1-\beta>80 \%)$. 
First order interactions between the different factors were tested: macrophyte species $\times$ sampling dates ( 6 degrees of freedom, $d f$ ), macrophyte species $\times$ water velocity $(1 d f)$, sampling dates $\times$ water velocity $(6 d f)$. Second order interaction $(6 d f)$ corresponds to error term because we had no replication.

All statistical analyses were conducted with Minitab for Windows (version 13, Minitab Inc., USA) and a significance level of $P<0.05$ was used.

\section{Results}

$B$. erecta occurred over a wide range of water velocities $\left(0.03-0.96 \mathrm{~m} \mathrm{~s}^{-1}\right)$, water phosphorus content $\left(0-46 \mu \mathrm{g} \mathrm{l}^{-1}\right)$ and sediment phosphorus content (0.2-2.2 $\mathrm{mg} \mathrm{g}^{-1}$ dry mass). Shoot phosphorus content ranged from 1.1 to $9.4 \mathrm{mg} \mathrm{g}^{-1}$ dry mass, whereas root phosphorus content of some plants ranged from 0.6 to $18.7 \mathrm{mg} \mathrm{g}^{-1}$. Sediment phosphorus content was relatively similar among sampling stations, except for the station 13 where it exceeded $1 \mathrm{mg} \mathrm{g}^{-1}$ dry mass, and which was associated with a high root phosphorus content (8.5 $\mathrm{mg} \mathrm{g}^{-1}$ dry mass). Similarly, C. obtusangula was found in a wide range of conditions, characterized by a water velocity ranging from 0.03 to $0.67 \mathrm{~m} \mathrm{~s}^{-1}$, water phosphorus content from close to 0 to $45.5 \mu \mathrm{g} \mathrm{l}^{-1}$, and sediment phosphorus content from 0.2 to $1.4 \mathrm{mg} \mathrm{g}^{-1}$ dry mass. Shoot phosphorus content was also in the same magnitude as $B$. erecta, from 1.4 to $9.2 \mathrm{mg} \mathrm{g}^{-1}$ dry mass.

Stations were separated in two groups according to their water velocity: low ("L": $V \leq 0.4 \mathrm{~m} / \mathrm{s}$ ) and high ("H": $V>0.4 \mathrm{~m} / \mathrm{s}$ ), considering species separately and all sampling dates for each species. $T$-tests performed on phosphorus content of plant, water and sediment in the two groups of stations showed no significant difference in water or sediment phosphorus content (Table 2). For $B$. erecta, shoot and root phosphorus content was also similar in the two groups. On the contrary, $C$. obtusangula showed higher shoot phosphorus content in stations with low water velocity compared to those of high water velocity.

For both species, water, sediment or plant phosphorus content were not correlated with water velocity (Table 3). Water phosphorus content was negatively correlated with sediment phosphorus content for C. obtusangula sites, but not $B$. erecta sites. Water phosphorus content was positively correlated with shoot and root phosphorus content for B. erecta (Table 3). Root phosphorus content was also positively correlated to shoot phosphorus content of B. erecta (Table 3).

For the stream Ischert where both species cooccur, shoot phosphorus content was significantly affected by sampling date and water velocity, effect of the species was not significant (Table 4), and interaction between species and dates, species and water velocity, dates and water velocity were significant (Table 4, Figs. 1, 2, 3). Shoot phosphorus content was high during the growing season (from August to October, from 5 to $9 \mathrm{mg} \mathrm{g}^{-1} \mathrm{DM}$ ) and low during the winter (from January to March, $<4 \mathrm{mg} \mathrm{g}^{-1} \mathrm{DM}$ ), when water velocity was low (Figs. 2b, 3b). When water velocity was high, time period effect almost disappeared (Fig. 3b) and shoot phosphorus contents were about $3.5 \mathrm{mg} \mathrm{g}^{-1}$ DM (Fig. 2b). Variations between time period were more important for $C$. obtusangula than for B. erecta (Fig. 1a), but shoot phosphorus content of $B$. erecta increased earlier than the one of $C$. obtusangula at the end of the winter (Fig. 2a).

In this stream, shoot phosphorus content was significantly higher at low velocity for both species (Table 4), but differences of shoot phosphorus content between the two water velocities were more pronounced for $C$. obtusangula than for $B$. erecta (differences of 2.8 and $1.1 \mathrm{mg} \mathrm{g}^{-1} \mathrm{DM}$, for $C$. obtusangula and $B$. erecta, respectively, Figs. 1b, 3a).

\section{Discussion}

Our results on total phosphorus content of the different compartments (water, sediment, shoots and roots) fall well within the large range of values observed from laboratory conditions (Best et al., 1996) and lakes (De Groot \& Golterman, 1990; Svendsen et al., 1993), rivers (Clarke \& Wharton, 2001) and streams (Robach et al., 1995) experiments. 
Table 2 Mean (standard deviation) water velocity, total phosphorus (P) content of water, sediment, shoots and roots (only for $B$. erecta) in the low water velocity and in the high water velocity sampling stations, for B. erecta and C. obtusangula

\begin{tabular}{|c|c|c|c|}
\hline & Low velocity & High velocity & $P$ value \\
\hline \multicolumn{4}{|l|}{ B. erecta } \\
\hline Velocity $\left(\mathrm{m} \mathrm{s}^{-1}\right)$ & $0.17(0.10)$ & $0.50(0.12)$ & 0.000 \\
\hline Water $\mathrm{P}\left(\mu \mathrm{g}^{-1}\right)$ & $11.13(10.06)$ & $9.83(8.19)$ & 0.384 \\
\hline Sediment $\mathrm{P}\left(\mathrm{mg} \mathrm{g}^{-1}\right)$ & $0.53(0.23)$ & $0.61(0.40)$ & 0.226 \\
\hline Shoot $\mathrm{P}\left(\mathrm{mg} \mathrm{g}^{-1}\right)$ & $3.23(1.46)$ & $3.60(1.08)$ & 0.079 \\
\hline Root $\mathrm{P}\left(\mathrm{mg} \mathrm{g}^{-1}\right)$ & $4.13(2.91)$ & $4.16(2.13)$ & 0.955 \\
\hline \multicolumn{4}{|l|}{ C. obtusangula } \\
\hline Velocity $\left(\mathrm{m} \mathrm{s}^{-1}\right)$ & $0.17(0.11)$ & $0.47(0.08)$ & 0.000 \\
\hline Water $\mathrm{P}\left(\mu \mathrm{g}^{-1}\right)$ & $14.34(11.74)$ & $11.74(9.05)$ & 0.163 \\
\hline Sediment $\mathrm{P}\left(\mathrm{mg} \mathrm{g}^{-1}\right)$ & $0.58(0.26)$ & $0.63(0.30)$ & 0.483 \\
\hline Shoot $\mathrm{P}\left(\mathrm{mg} \mathrm{g}^{-1}\right)$ & $4.28(1.76)$ & $3.61(1.24)$ & 0.010 \\
\hline
\end{tabular}

$P$ values correspond to $T$-tests results

Table 3 Matrix of Pearson correlation analysis between water velocity, total phosphorus (P) content of the water, sediment, shoots and roots (only for B. erecta) of B. erecta and C. obtusangula

\begin{tabular}{|c|c|c|c|c|}
\hline & Water $\mathrm{P}\left(\mu \mathrm{g}^{-1}\right)$ & Shoot $\mathrm{P}\left(\mathrm{mg} \mathrm{g}^{-1}\right)$ & Root $\mathrm{P}\left(\mathrm{mg} \mathrm{g}^{-1}\right)$ & Sediment $\mathrm{P}\left(\mathrm{mg} \mathrm{g}^{-1}\right)$ \\
\hline \multicolumn{5}{|l|}{ B. erecta } \\
\hline Shoot $\mathrm{P}\left(\mathrm{mg} \mathrm{g}^{-1}\right)$ & $0.445 * * *$ & & & \\
\hline Root $\mathrm{P}\left(\mathrm{mg} \mathrm{g}^{-1}\right)$ & $0.400 * * *$ & $0.787 * * *$ & & \\
\hline Sediment $\mathrm{P}\left(\mathrm{mg} \mathrm{g}^{-1}\right)$ & -0.133 & -0.092 & 0.057 & \\
\hline Velocity $\left(\mathrm{m} \mathrm{s}^{-1}\right)$ & -0.020 & 0.134 & 0.019 & -0.132 \\
\hline \multicolumn{5}{|l|}{ C. obtusangula } \\
\hline Shoot P $\left(\mathrm{mg} \mathrm{g}^{-1}\right)$ & 0.036 & & & \\
\hline Sediment $\mathrm{P}\left(\mathrm{mg} \mathrm{g}^{-1}\right)$ & $-0.260 *$ & 0.130 & & \\
\hline Velocity $\left(\mathrm{m} \mathrm{s}^{-1}\right)$ & -0.052 & -0.064 & & 0.128 \\
\hline
\end{tabular}

$*(0.05<P<0.01)$

$* * *(P<0.001)$

C. obtusangula showed no correlation between shoot content and water content, or between shoot content and sediment content, suggesting

Table 4 Unreplicated three factor ANOVA results (species, sampling dates and water velocity) at two sampling stations of one stream (Ischert low water velocity stations $\mathrm{L}$, and high water velocity stations $\mathrm{H}$ ) and on the shoot total phosphorus content of $C$. obtusangula and B. erecta

\begin{tabular}{llrrl}
\hline Source of variation & $d f$ & \multicolumn{1}{l}{ MS } & \multicolumn{1}{l}{ F } & $P$ \\
\hline Species & 1 & 0.0291 & 0.07 & 0.807 \\
Dates & 6 & 5.0841 & 11.40 & 0.005 \\
Water velocity & 1 & 26.0068 & 58.30 & 0.000 \\
Species $\times$ dates & 6 & 2.2462 & 5.04 & 0.035 \\
Species $\times$ water velocity & 1 & 2.9660 & 6.65 & 0.042 \\
Dates $\times$ water velocity & 6 & 5.7615 & 12.92 & 0.003 \\
Error & 6 & 0.4461 & & \\
Total & 27 & & & \\
\hline
\end{tabular}

that this species does not have any preferential strategy, or that sediment or water phosphorus is in excess of plant needs. However, For B. erecta, we found a positive correlation between plant (shoot and root) and water phosphorus content, but none between plant and sediment phosphorus content. This result may suggest that phosphorus can be absorbed by shoots from water and translocated to roots. The occurrence of phosphorus absorption by shoots is confirmed by previous work in the same and others Alsatian floodplain hardwater streams (Robach et al., 1995; Robach et al., 1996). In addition, translocation from shoots to roots has been observed during indoor experiments using ${ }^{32} \mathrm{P}$ incubation (De Marte \& Hartman, 1974; Bole \& Allan, 1978; Welsh \& Denny, 1979; Rattray et al., 1991; Eugelink, 1998). 

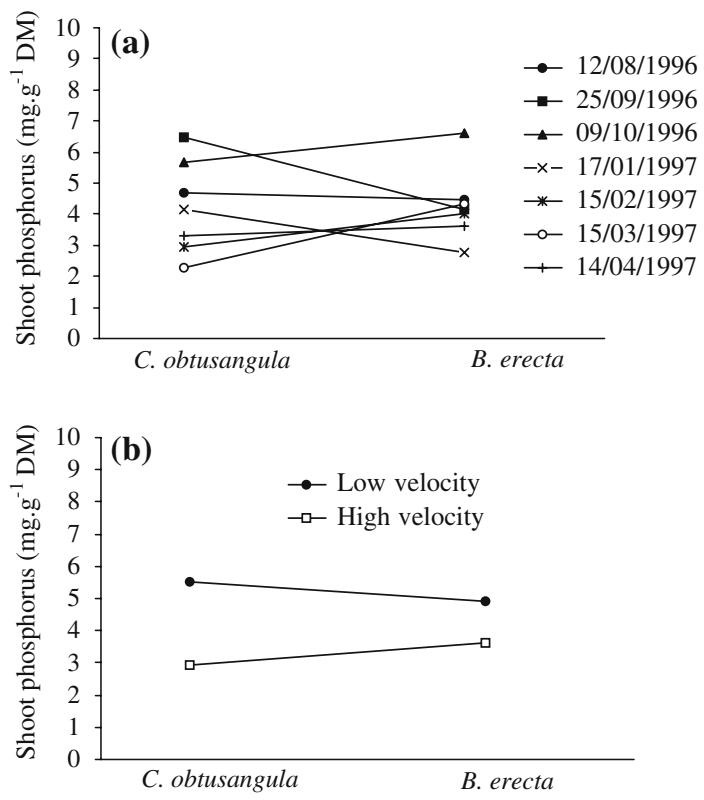

Fig. 1 Interaction diagrams (means of shoots total phosphorus content in $\mathrm{mg} \mathrm{g}^{-1}$ of $\mathrm{P}-\mathrm{PO}_{4}^{3-}$ ) between species $\times$ dates (a) and species $\times$ water velocity (b) of the ANOVA performed on the Ischert stream (low water velocity stations and high water velocity stations, for both species $C$. obtusangula and $B$. erecta, and seven sampling dates)

Our results suggest that aquatic macrophytes can potentially use two sources of available phosphorus: water and sediment, and that the strategy can change among species and with nutrient supply in each compartment. This process implies that phosphorus can be translocated from shoots to roots or from roots to shoots, which has been showed in laboratory studies (De Marte \& Hartman, 1974; Eugelink, 1998). If shoot absorption is debated, root uptake of phosphorus is common accepted as the mode of nutrition (Patriquin, 1972; Bole \& Allan, 1978; Best \& Mantai, 1979; Barko \& Smart, 1981; Barko et al., 1988). Even macrophytes with limited root systems have been shown to uptake phosphorus via roots (Barko \& James, 1998). However, the sediment compartment appears as a source of nutrient supply to rooted plants mainly when nutrients are not sufficiently available in the water (Bole \& Allan, 1978; Barko \& Smart, 1981). This is confirmed in our study at station 13 for $B$. erecta. The sediment phosphorus content is high and the water phosphorus content is low. Plant tissues (roots and shoots) from station 13 present a high phosphorus content compared to the other stations, then phosphorus might have been absorbed by roots and translocated to shoots.

In the stream Ischert, shoot phosphorus storage was significantly lower in the high water velocity stations, whatever the species. Limited information is available on the influence of water velocity on phosphorus uptake by macrophytes. Water velocity may cause a decrease in phosphorus uptake by impeding nutrient adsorption (Boeger, 1992) or it may increase phosphorus uptake by increasing the amount of available ions in the water or sediment (Jarvie et al., 2002). Our results are consistent with the first assertion. In addition, the same phenomenon has been found for algae in streams as the growth of algae in
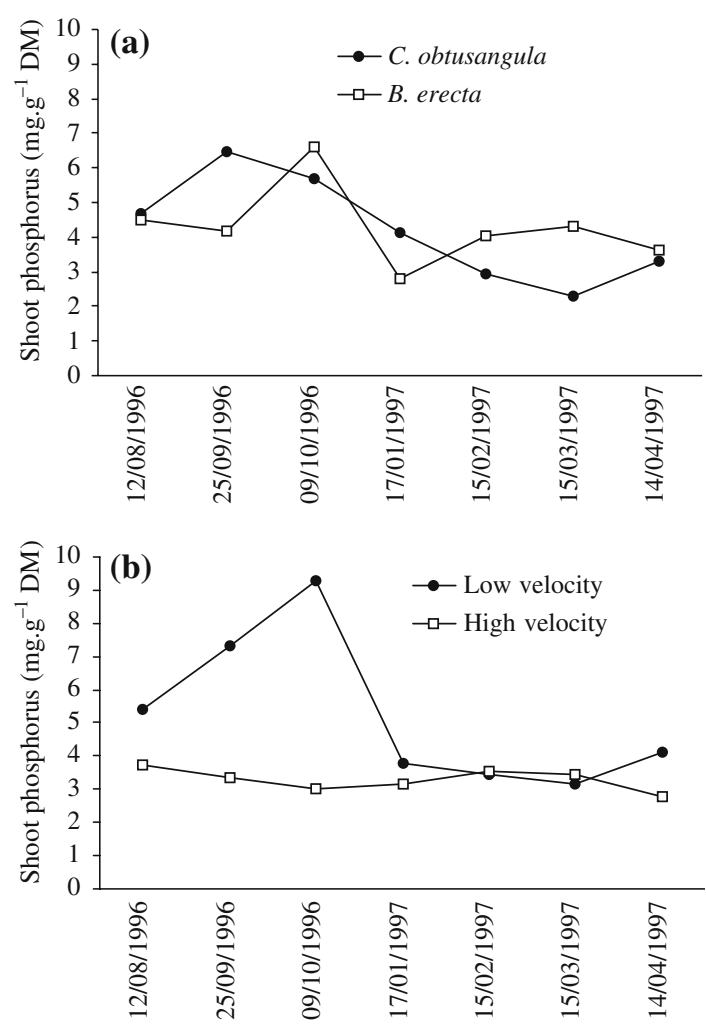

Fig. 2 Interaction diagrams (means of shoots total phosphorus content in $\mathrm{mg} \mathrm{g}^{-1}$ of $\mathrm{P}-\mathrm{PO}_{4}^{3-}$ ) between dates $\times$ species (a) and dates $\times$ water velocity (b) of the ANOVA performed on the Ischert stream (low water velocity stations and high water velocity stations, for both species $C$. obtusangula and B. erecta, and seven sampling dates) 

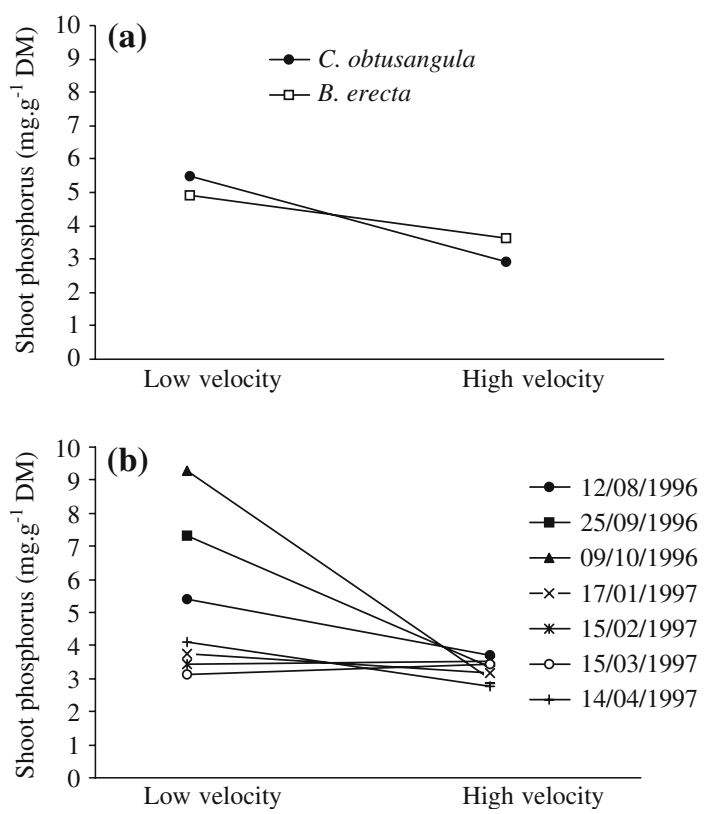

Fig. 3 Interaction diagrams (means of shoots total phosphorus content in $\mathrm{mg} \mathrm{g}^{-1}$ of $\mathrm{P}-\mathrm{PO}_{4}^{3-}$ ) between water velocity $\times$ species (a) and water velocity $\times$ dates $(\mathbf{b})$ of the ANOVA performed on the Ischert stream (low water velocity stations and high water velocity stations, for both species $C$. obtusangula and $B$. erecta, and seven sampling dates)

response to increased nutrient levels decreases with current velocity (Ghosh \& Gaur, 1994).

By comparing the two macrophytes species in the stream Ischert, we found that $C$. obtusangula was more sensitive than $B$. erecta to the variation of water velocity. Indeed, the shoot phosphorus content of $C$. obtusangula was higher in low velocity stations and lower in high velocity stations, although $B$. erecta showed no marked differences. These differences could be explained by their morphology and ecology. C. obtusangula stores phosphorus more efficiently in its shoots in low velocity than in high velocity conditions. This species is weakly rooted and prefers pool habitat due to low velocities that are optimal for nutrient storage and biomass development. In contrast, $B$. erecta is strongly rooted, colonizes riffles, and stores more phosphorus under high water velocity conditions. Moreover, as Boeger (1992) observed, the water velocity effect may be mediated by the substratum. Then this effect could be different according to sampling sites where our species occurred, as $B$. erecta grows preferentially on coarse substrate (gravel) at high velocities, by contrast with $C$. obtusangula, which grows on finer sediments (sand, mud) at low velocities.

The temporal pattern of shoot phosphorus observed in this study is in accordance with current concepts on aquatic macrophyte nutrition (review in Reddy et al., 1999). Phosphorus uptake increases in spring, up to a maximum during the peak growing season (summer and autumn) and decreases in winter. However, the time period had an effect on plant phosphorus content only when the water velocity was low. This last result indicates that the relative importance of different factors involved in phosphorus storage by plant can change, and that it is inaccurate to view phosphorus storage as the product of only a single variable, but should be seen as result multiple factors.

Acknowledgements We thank N. Korboulewsky, S. Greulich and anonymous reviewers for advice and critical commentary on the manuscript. This work was supported by the "Institut Franco-Allemand de Recherche sur l'Environnement" (IFARE/ULP/CNRS/Alsace Region).

\section{References}

AFNOR, 1986. Recueil des normes françaises: Eaux méthodes d'essai. NF T90-023 pp 270-279 AFNOR ed.

Barko, J. W. \& W. F. James, 1998. Effects of submerged aquatic macrophytes on nutrient dynamics, sedimentation, and resuspension. In Sondergaard, J. \& C. Sondergaard (eds), The structuring role of submerged macrophytes in lakes. Springer Verlag, New York, 197-214.

Barko, J. W. \& R. M. Smart, 1980. Mobilisation of sediment phosphorus by submerged freshwater macrophytes. Freshwater Biology 10: 229-238.

Barko, J. W. \& R. M. Smart, 1981. Sediment-based nutrition of submerged macrophytes. Aquatic Botany 10: 339-352.

Barko, J. W., R. M. Smart, D. G. McFarland \& R. L. Chen, 1988. Interrelationships between the growth of Hydrilla verticillata (L.f.) Royle and sediment nutrient availability. Aquatic Botany 32: 205-216.

Best, M. D. \& K. E. Mantai, 1979. Growth of Myriophyllum: sediment or lake water as the source of nitrogen and phosphorus. Ecology 59: 1075-1080.

Best, E. P. H., H. Woltman \& F. H. H. Jacobs, 1996. Sediment-related growth limitation of Elodea nuttallii as indicated by a fertilization experiment. Freshwater Biology 36: 33-44. 
Boeger, R. T., 1992. The influence of substratum and water velocity on growth of Ranunculus aquatilis L. (Ranunculaceae). Aquatic Botany 42: 351-359.

Bole, J. B. \& J. R. Allan, 1978. Uptake of phosphorus from sediment by aquatic plants, Myriophyllum spicatum and Hydrilla verticillata. Water Research 12: 353-358.

Carignan, R. \& J. Kalff, 1980. Phosphorus source for aquatic weeds: water or sediment. Science 207: 987988.

Carr, G. M. \& P. A. Chambers, 1998. Macrophyte growth and sediment phosphorus and nitrogen in a Canadian prairie river. Freshwater Biology 39: 525-536.

Chambers, P. A. \& E. E. Prepas, 1994. Nutrient dynamics in riverbeds: the impact of sewage effluent and aquatic macrophytes. Water Research 28: 453-464.

Chambers, P. A., E. E. Prepas, M. L. Bothwell \& H. R. Hamilton, 1989. Roots versus shoots in nutrient uptake by aquatic macrophytes in flowing waters. Canadian Journal of Fisheries and Aquatic Sciences 46: 435-439.

Chambers, P. A., E. E. Prepas \& K. Gibson, 1992. Temporal and spatial dynamics in riverbed chemistry: the influence of flow and sediment composition. Canadian Journal of Fisheries and Aquatic Sciences 49: 21282140.

Clarke, S. J. \& G. Wharton, 2001. Sediment nutrient characteristics and aquatic macrophytes in lowland English rivers. The Science of the Total Environment 266: 103-112.

Dawson, F. H. 1988. Water flow and the vegetation of running waters. In Symoens, J. J. (ed.), Vegetation of inland waters. Kluwer, The Netherlands: 283-308.

DeGroot, C. J. \& H. L. Golterman, 1990. Sequential fractionation of sediment phosphate. Hydrobiologia 192: 143-148.

DeMarte, J. A. \& R. T. Hartman, 1974. Studies on absorption of ${ }^{32} \mathrm{P},{ }^{59} \mathrm{Fe}$ and ${ }^{45} \mathrm{Ca}$ by water-milfoil (Myriophyllum exalbescens Fernald). Ecology 55: 188-194.

Denny, P., 1972. Sites of nutrient absorption in aquatic macrophytes. Journal of Ecology 60: 819-829.

Eglin, I. \& F. Robach, 1992. Typologie et végétation de l'hydrosystème rhénan dans le secteur central de la plaine d'Alsace : interpretation et fonctionnement écologique. I. Unités fonctionnelles connectées au Rhin. II. Unités fonctionnelles déconnectées du Rhin. Thèse de Doctorat. Université Louis Pasteur, Strasbourg I, $342 \mathrm{pp}$.

Eugelink, A. H., 1998. Phosphorus uptake and active growth of Elodea canadensis Michx. and Elodea nuttallii (Planch) St John. Water Science Technology 37: 59-65.

Fogg, G. E., 1973. Phosphorus in primary aquatic plants. Water Research 7: 77-91.

Gabrielson, J. O., M. A. Perkins \& E. B. Welsh, 1984. The uptake, translocation and release of phosphorus by Elodea densa. Hydrobiologia 111: 43-48.

Ghosh, M. \& J. P. Gaur, 1994. Algal periphyton of an unshaded stream in relation to in situ nutrient enrichment and current velocity. Aquatic Botany 47: 185-189.
Haslam, S. M., 1982. A proposed method for monitoring rivers pollution using macrophytes. Science and Technology 3: 19-34.

Haslam, S. M., 1990. River pollution: an ecological perspective. Belhaven Press, London and New York.

Hawkes, H. A., 1962. Biological aspects of river pollution. In Klein L. (ed.), River pollution: causes and effects. Butterworths, London, 311-432.

Hill, B. H., 1979. Uptake and release of nutrients by aquatic macrophytes. Aquatic Botany 7: 87-93.

House, W. A. \& F. H. Denison, 2002. Total phosphorus content of river sediments in relationship to calcium, iron and organic matter concentrations. The Science of the Total Environment 282-283: 341-351.

Huebert, D. B. \& P. R. Gorham, 1983. Biphasic mineral nutrition of the submersed aquatic macrophyte Potamogeton pectinatus. Aquatic Botany 16: 269-284.

Jarvie, H. P., C. Neal, R. J. Williams, M. Neal, H. Wickham, L. K. Hill, A. J. Wade, A. Warwick \& J. White, 2002. Phosphorus sources, speciation and dynamics in the lowland eutrophic River Kennet, UK. The Science of the Total Environment 282-283: 175-203.

Löfgren, S. \& B. Boström, 1989. Intestitial water of phosphorus, iron, and manganese in a shallow eutrophic swedish lake - Implications for phosphorus cycling. Water Research 23: 1115-1125.

Maine, A. M., N. L. Suñe, M. C. Panigatti, M. J. Pizarro \& F. Emiliani, 1999. Relationships between water chemistry and macrophyte chemistry in lotic and lentic environments. Archiv für Hydrobiology 145: 129-145.

Moutin, T., B. Picot, M. C. Ximenes \& J. Bontoux, 1993. Seasonal variations of $\mathrm{P}$ compounds and their concentrations in two coastal lagoons (Hérault France). Hydrobiologia 252: 45-59.

Patriquin, D. G., 1972. The origin of nitrogen and phosphorus for growth of the marine angiosperm Thalassia testudinum. Marine Biology 15: 35-46.

Pelton, D. K., S. N. Levine \& M. Braner, 1998. Measurements of phosphorus uptake by macrophytes and epiphytes from the Laplatte River using ${ }^{32} \mathrm{P}$ in stream microcosms. Freshwater Biology 39: 285-299.

Peverly, J. H., 1979. Elemental distribution and macrophyte growth downstream from an organic soil. Aquatic Botany 7: 319-338.

Peverly, J. H., 1985. Element accumulation and release by macrophytes in a wetland stream. Journal of Environmental Quality 14: 137-143.

Prairie, Y. T. \& J. Kalff, 1988. Dissolved phosphorus dynamics in headwater streams. Canadian Journal of Fisheries and Aquatic Sciences 45: 200-209.

Quinn, G. P. \& M. J. Keough, 2002. Experimental design and data analysis for biologists. Cambridge University Press (ed), UK.

Rattray, M. R., C. H. Williams \& J. M. A. Brown, 1991. Sediment and water as sources of nitrogen and phosphorus for submerged rooted aquatic macrophytes. Aquatic Botany 40: 225-237.

Reddy, K. R., R. H. Kadlec, E. Flaig \& P. M. Gale, 1999. Phosphorus retention in streams and wetlands: a review. Critical reviews in environmental science and technology 29: 83-146. 
Robach, F., I. Hajnsek, I. Eglin \& M. Trémolières, 1995. Phosphorus sources for aquatic macrophytes in running water: water or sediment? Acta botanica Gallica 142: 719-731.

Robach, F., S. Merlin, T. Rolland \& M. Trémolières, 1996. Assimilation et stockage du phosphore par des macrophytes aquatiques bioindicateurs du niveau trophique de l'eau. Ecologie 27: 203-214.

Royle, R. N. \& R. J. King, 1991. Aquatic macrophytes in Lake Liddell, New South Wales: biomass, nitrogen and phosphorus status and changing distribution from 1981 to 1987 Aquatic Botany 41: 281-298.

Sanchez-Pérez J. \& M. Trémolières, 2003. Change in groundwater chemistry as a consequence of suppression of floods: the case of the Rhine floodplain. Journal of Hydrology 16: 89-104.

Schachtman, D. P., R. J. Reid \& S. M. Ayling, 1998. Phosphorus uptake by plants: from soil to cell. Plant Physiology 116: 447-453.

Smith, F. W., S. R. Mudge \& A. L. Rae, 2003. Phosphate transport in plants. Plant Soil 248: 71-83.
Sokal, R. R. \& F. J. Rohlf, 1995. Biometry: the principles and practice of statistics in biological research. 3rd edn. W. H. Freeman and Co. (eds), New York.

Svendsen, L. M., A. Rebsdorf \& P. Nornberg, 1993. Comparison of methods for analysis of organic and inorganic phosphorus in river sediment. Water research 27: 77-83.

Van Huet, H. J. W. J., 1990. Phosphorus eutrophication research in the lake district of south estern Friesland, The Netherlands. Preliminary results of abiotic studies. Hydrobiologia 191: 75-85.

Vollenweider, R. A., 1971. Les bases scientifiques de l'eutrophisation des lacs et eaux courantes sous l'aspect particulier du phosphore et de l'azote comme facteurs d'eutrophisation. Rapport bibliographique de l'Organisation de Coopération et de Développement Economiques, Paris, 182 pp.

Welsh, R. P. H. \& P. Denny, 1979. The translocation of $32 \mathrm{P}$ in two submerged aquatic angiosperm species. New Phytologist 82: 645-656. 